Article

\title{
Migration, Rural-Urban Connectivity, and Food Remittances in Kenya
}

\author{
Elizabeth Opiyo Onyango ${ }^{1}$, Jonathan Crush ${ }^{1,2,3, *}$ and Samuel Owuor ${ }^{4} \mathbb{C}$ \\ 1 Balsillie School of International Affairs, Waterloo, ON N2L 6C2, Canada; eopiyoonyango@uwaterloo.ca \\ 2 School of International Policy and Governance, Wilfrid Laurier University, Waterloo, ON N2L 6C2, Canada \\ 3 Department of Geography, Environment and Tourism, University of the Western Cape, \\ Cape Town 7535, South Africa \\ 4 Department of Geography and Environmental Studies, University of Nairobi, Nairobi 00100, Kenya; \\ samowuor@uonbi.ac.ke \\ * Correspondence: jcrush@balsillieschool.ca
}

Citation: Onyango, E.O.; Crush, J.; Owuor, S. Migration, Rural-Urban Connectivity, and Food Remittances in Kenya. Environments 2021, 8, 92. https://doi.org/10.3390/ environments8090092

Academic Editors: Gianluca Brunori and Sabrina Arcuri

Received: 27 June 2021

Accepted: 25 August 2021

Published: 7 September 2021

Publisher's Note: MDPI stays neutral with regard to jurisdictional claims in published maps and institutional affiliations.

Copyright: (c) 2021 by the authors. Licensee MDPI, Basel, Switzerland. This article is an open access article distributed under the terms and conditions of the Creative Commons Attribution (CC BY) license (https:// creativecommons.org/licenses/by/ $4.0 /)$.

\begin{abstract}
This paper draws on data from a representative city-wide household food security survey of Nairobi conducted in 2017 to examine the importance of food remitting to households in contemporary Nairobi. The first section of the paper provides an overview of the urbanization and rapid growth of Nairobi, which has led to growing socio-economic inequality, precarious livelihoods for the majority, and growing food insecurity, as context for the more detailed empirical analysis of food security and food remittances that follows. It is followed by a description of the survey methodology and sections analyzing the differences between migrant and non-migrant households in Nairobi. Attention then turns to the phenomenon of food remitting, showing that over $50 \%$ of surveyed households in the city had received food remittances in the previous year. The paper then uses multivariate logistic regression to identify the relationship between Nairobi household characteristics and the probability of receiving food remittances from rural areas. The findings suggest that there are exceptions to the standard migration and poverty-driven explanatory model of the drivers of rural-urban food remitting and that greater attention should be paid to other motivations for maintaining rural-urban connectivity in Africa.
\end{abstract}

Keywords: urban household; migration; connectivity; food remittances; food security; Nairobi; Kenya

\section{Introduction}

A progressively greater share of the population of sub-Saharan Africa is living permanently or semi-permanently in towns and cities [1]. Some have argued that African urbanization is driven primarily by natural population growth, while others have convincingly demonstrated that migrants make up a large proportion of the population in many urban areas [2-4]. Migrants to cities do not generally or immediately cut their links with rural homes, and there is a large body of literature on the character, types, and implications of connections between rural areas and rapidly urbanizing cities dating back to at least the 1980s [5-10]. However, recent studies have suggested that rapid urbanization requires a reconceptualization of the dominant linear view of migrants relocating to cities and sending cash remittances to relatives left behind in the countryside. One recent study argues, for example, that the relationship between those in cities and those left behind in rural areas is far from linear and that "complexity and diversity are fundamental characteristics of rural-urban linkages" [11]. They go on to redefine such linkages as "constantly evolving webs of connections between urban and rural spaces and dimensions" [11]. Another goes even further, arguing for the deconstruction of the conventional rural-urban dichotomy entirely, since the livelihoods of the majority of geographically separated 'rural' and 'urban' households are completely intertwined such that "rural and urban, defined in the traditional way, are conceptual lenses that distort our view of the reality of social processes 
and can only lead to sub-optimal policies and interventions" [12]. Writing from the rural perspective, others have suggested that urban and rural households should not be seen as separate entities but essentially part of the same geographically dispersed or translocal household pursuing multi-local livelihood strategies [13,14].

There is a long history of research on the rural drivers of migration to urban areas in Kenya, most notably the influential two-sector Harris-Todaro economic model of household decision-making about migration from the 1960s $[15,16])$. Simultaneously, Walter Elkan promoted the idea of circular migration in the Kenya context, suggesting that urbanization was an essentially impermanent phenomenon [17]. As he noted, "part of the urban populations in East Africa and elsewhere consists of people who continue to have close connections with their villages of origin, to which they may ultimately return [17] (p. 581). Over forty years later, Oucho et al. painted essentially the same picture in their study of rural-urban migration to Kisumu and Nairobi, noting that migrants "maintain strong contacts with their origins, to where they send remittances for relatives left behind. At the end of a migratory life, the vast majority of migrants expect to return to their homes to try and lead better lives than non-migrant folk, and to develop their communities as well as their counties of origin" [18] (p. 1). While there is some evidence of a decline in return migration of the elderly, the persistence of circular migration and the perpetuation of rural-urban connectivity over time remains a distinctive feature of Kenyan urbanization. As many as $80 \%$ of older migrants in Nairobi slums maintained contact with their rural origin homes during a full year of recent observation, and "patterns and reasons of linkages are consistent with migrants' positive contributions to the upkeep of rural origin households" [19] (p. 275).

One of the most widely documented forms of rural-urban connectivity in Kenya is the flow of cash remittances from urban-based migrants to their rural relatives [20-22]. The rapid development of the mobile money MPESA system since 2007 has clearly demonstrated both the sizable volume and urban-rural directionality of cash remitting in the country $[23,24]$. While there is a wealth of research on migrant remittances more generally, the relationship between remittance use and food security has been undervalued [25]. This is consistent with a broader neglect of the connections between international and internal migration and food security [26-28]. More recently, several studies have demonstrated that there is a positive macro-level relationship between food security and the volume of remittances received [29-32].

National household survey data from Kenya suggest that low-income households are the greatest beneficiaries of cash remittances. While the remittances literature in Kenya generally focuses on the investment of remittances in agricultural production, there is more general evidence that a primary use of cash remittances in rural areas is food purchasing [33]. One study, for example, argues that many rural dwellers in Africa buy more food than they sell and, as net food buyers, are from low-income households who depend on remittances to access purchased food [34]. A survey of migrant-sending households in Southern Africa found that $82 \%$ spend remittances on food, while only $24 \%$ invest remittances in agricultural activity [35]. Only $7 \%$ of households received any income from the sale of farm produce. In addition to cash remittances, one-third of migrant-sending households received remittances in the form of goods, including food.

Food remitting has received relatively little attention in comparison with the large volume of research on the drivers and impacts of cash remittances [36]. So, too, has the impact of cash and goods remitting on the food security of remittance senders living in urban areas been overlooked [28]. This paper addresses another aspect of the relationship between remittances and food security: that is, the informal transfer or remitting of food from rural areas to migrants in the city, a phenomenon argued to be a common accompaniment to rapid urbanization [37-39]. Informal food remittances from rural households are significant in volume and play an important role in the diet of migrants living in low-income areas of the city of Windhoek, Namibia [40-42]. Other studies have confirmed that these 'food pathways' are much more common than previously assumed, although their importance 
varies considerably from country to country and city to city [36,42-44]. A large-scale study of 11 cities in nine countries by the African Food Security Urban Network (AFSUN) found that nearly three in every ten households in low-income neighbourhoods had received food remittances in the previous year but that this varied from $14 \%$ in Johannesburg to over $40 \%$ in Harare, Lusaka, and Windhoek [38]. Another large study of over 3,000 rural households in nine African countries found that one third remitted maize to towns within and outside their district, $23 \%$ to the capital city and $17 \%$ to other urban centres [13]. In small-town Kenya, urban households with active rural-urban linkages "enjoy significant transfers of food from rural areas that offset hunger and vulnerability in the urban context" [43] (p. 119). However, there have been no studies to date of the phenomenon of rural-to-urban food remitting in the capital and largest city of Nairobi.

\section{Materials and Methods}

This paper draws on data from the Hungry Cities Partnership (HCP) Food Security Household Survey for Nairobi City conducted in 2017 [45]. The survey interviewed a total of 1,434 households across the city. To generate a representative city-wide sample, a three-stage cluster sampling and probability proportional to size sampling was used. The survey was conducted in randomly selected administrative sub-locations spread across all of the administrative districts (or sub-counties) and divisions of Nairobi City County. Nairobi is divided into four administrative districts (or sub-counties): Nairobi West, Nairobi East, Nairobi North, and Westlands. These districts are further sub-divided into eight administrative divisions: Dagoretti and Kibera (in Nairobi West); Embakasi and Makadara (in Nairobi East); Central, Kasarani, and Pumwani (in Nairobi North); and Westlands division (in Westlands). These divisions are further divided into a total of 49 administrative locations. Lastly, the locations are split into 111 sub-locations, which are the lowest administrative units in Kenya. The survey covered randomly selected households in 23 of the 111 administrative sub-locations of Nairobi. In the selected 23 sub-locations, systematic random sampling method was used to identify the participating households, where every nth household was recruited and interviewed. The household head was the target interviewee in this survey. The data were collected in face-to-face interviews by experienced and trained enumerators.

To identify any observable differences between migrants and non-migrants, households with heads born in rural Kenya and those born in Nairobi were first cross-tabulated with a set of individual and household characteristics. Individual variables included the age, sex, education and employment status of the household head. Household characteristics included household size, type, main source of income, average monthly income, and lived poverty. The two sets of households were also compared in terms of whether they had received a food transfer at any time in the previous year, the proportion of income spent on food and their level of food security. Food security was measured using indicators developed by the Food and Nutrition Technical Assistant (FANTA) project. Household food insecurity was measured as a score ranging from 0-27 (HFIAS Scale) and transformed via the FANTA algorithm into a categorical variable (the HFIAP typology). Each household was assigned to one of four categories: (a) food secure; (b) mildly food insecure; (c) moderately food insecure; and (d) severely food insecure. Because household food insecurity is related to the proportion of household income spent on food, this predictor variable was also divided into four categories of progressively greater proportion from $<20 \%$ to $>50 \%$. The Lived Poverty Index (LPI) is a robust self-assessment tool for measuring the frequency with which households go without certain basic needs (food, water, medical care, cooking fuel, and cash income) measured on a scale from never (0) to always (4) [46]. 
There is a suggestion in the literature that food remitting is part of a broader social economy of reciprocity, in which cash remittances flow from city to countryside and food remittances flow in the reverse direction [37]. To test this hypothesis, households were divided into remitters and non-remitters (based on whether they had sent cash remittances to the rural area in the previous year). A distinction was also made between migrant and non-migrant households in relation to the receipt and frequency of receiving food transfers, again using the one-year recall period. The analysis also looked at whether households had experienced any recent shocks to see if there was any relationship between household vulnerability to shocks and food transfers. Seventeen separate shocks were pre-identified and categorized into three groups: (a) economic (which included sudden food price increases, loss of income, and loss of employment); (b) sociopolitical (including political violence); and (c) biophysical (including disease and epidemics).

To determine the likelihood of a household receiving food remittances, the second part of the analysis uses multiple logistic regression to identify the variables most strongly associated with the receipt of food remittances. Model 1 tested the strength of the association between the dependent variable of food remittance receipt and individual predictor variables including the sex, age, education, and employment status of the household head. Model 2 introduced a second set of predictor variables relating to household characteristics. For household type, each household was classified into one of four groups: (a) femalecentred (female head with no partner or spouse present); (b) male-centred (male head with no partner or spouse present); (c) nuclear (two parents and children); and (d) extended (two parents and children plus other relatives and non-relatives). Similarly, four main types of household income were identified in the city: (a) formal wage work; (b) informal wage work; (c) informal self-employment; and (d) formal self-employment. Household income was divided into quintiles, and household poverty was based on the Lived Poverty Index. Model 3 tested the relationship between rural-urban food transfers and vulnerability to shocks after binning all responses based on whether a household had experienced any one of the three different types of shock in the previous six months.

The study data and results do have several limitations. First, income, poverty, and expenditure on food were self-reported and not verified independently. Second, the analysis assumes that household heads had perfect knowledge of all facets of the household, including its demographic characteristics, socio-economic profile, and the food consumption behaviour of all household members. Third, the study did not investigate the migrant status of individual household members, and it used age as a surrogate for the length of time the migrant heads had lived in Nairobi. Fourth, although data were collected on the types of food transferred, data on quantity and quality were not, and hence the nutritional value and impact of food transfers to the household was not verifiable. Fifth, the recall periods for food remitting (one year) and household shocks (six months) were not identical, so a causal relationship could not be asserted between shocks and food remitting. Sixth, the survey only collected data on rural-to-urban food remitting, not vice versa, although there is some evidence in other countries that this can be an important phenomenon [35]. Finally, throughout the analysis we refer to migrant and non-migrant households based on whether or not the head was born in a rural area or in Nairobi. In practice, many migrant households, particularly those with children, are more likely than their non-migrant counterparts to consist of a mix of migrant adults and Nairobi-born children.

\section{Results and Discussion}

Kenya is undergoing an accelerating shift of population from countryside to city. Currently, about $25 \%$ of Kenya's population is urban, with an annual growth rate of $4.4 \%$. The metro area population of the City of Nairobi was 4,397,073 in 2019 [47]. Although natural increase is a key contributor to Nairobi's population growth, in-migration is equally important in the city's population growth. Nairobi attracts migrants from all regions of Kenya in search of better economic opportunity. A significant proportion of the city's population are rural-urban migrants, particularly in the lower-income areas. A survey in 
the informal settlements of Korogocho and Viwandani, for example, found that $86 \%$ of the residents were migrants [48]. Social and economic inequality and high levels of poverty accompanying rapid urbanization are particularly evident in Nairobi. Poverty rates in the informal slum settlements of Kibera, Korogocho, and Mathare are over 60\%. By contrast, higher-income areas of the city such as Kileleshwa, Runda, and Karen have poverty rates under $5 \%$ [49].

In our city-wide household survey, $70 \%$ of household heads in Nairobi were born in rural areas of the country, with only about two in every ten household heads born in Nairobi. A further 5\% were born in other Kenyan cities, and the remainder were foreign-born. In this paper, we focus on the differences between the first two categories of migrant (rural-born) and non-migrant (Nairobi-born) household heads. The ratio of male to female household heads was almost identical in both groups (at 4:1) (Table 1). Given the emphasis in the migration literature on youth migration, the similarity in the age structure of migrant and non-migrant household heads is noteworthy [50-52]. In total, $40 \%$ of migrant household heads and $45 \%$ of non-migrant household heads were under the age of 35. The relative proportion of heads in each successive age band over 35 was very similar. The argument that all migrants inevitably return to the rural areas as they age was not fully born out, with $13 \%$ of migrant household heads and $9 \%$ of non-migrant household heads being over the age of 55 [18].

In theory, Nairobi-born household heads should have greater access to educational opportunities and labour market opportunities [53]. However, the survey again found considerable similarities between the two groups. The proportion of household heads in full-time employment was similar for both groups (41\% migrant and $43 \%$ non-migrant) (Table 1). Slightly more migrant heads were in part-time or casual work (15\% versus $10 \%)$, and fewer (although still a significant proportion) were self-employed ( $38 \%$ versus $42 \%$ ). The major difference between the two groups was in level of educational attainment, with Nairobi-born household heads tending to have slightly higher levels of education overall ( $90 \%$ versus $81 \%$ secondary or above). However, relatively high proportion of educated migrant heads is testimony to the widespread access to secondary schooling in Kenya's rural areas [54].

Table 1. Descriptive Characteristics of Migrant and Non-Migrant Households.

\begin{tabular}{|c|c|c|c|c|c|}
\hline \multirow[b]{2}{*}{$\begin{array}{l}\text { Characteristics of } \\
\text { Household Heads }\end{array}$} & \multicolumn{2}{|c|}{ Migrant-Headed (Rural Born) } & \multicolumn{2}{|c|}{ Non-Migrant-Headed (Nairobi-Born) } & \multirow[t]{2}{*}{$p$-Value } \\
\hline & Frequency & $\%$ & Frequency & $\%$ & \\
\hline Total & 874 & 76.7 & 266 & 23.3 & \\
\hline \multicolumn{5}{|c|}{ Sex of Household Head } & \multirow{3}{*}{0.429} \\
\hline Male & 717 & 82.9 & 217 & 82.2 & \\
\hline Female & 148 & 17.1 & 47 & 17.8 & \\
\hline \multicolumn{5}{|c|}{ Age of Household Head } & \multirow{7}{*}{0.108} \\
\hline $16-24$ & 64 & 7.4 & 32 & 12.1 & \\
\hline $25-34$ & 284 & 32.7 & 87 & 33.0 & \\
\hline $35-44$ & 285 & 32.8 & 88 & 33.3 & \\
\hline $45-54$ & 123 & 14.2 & 33 & 12.5 & \\
\hline $55-64$ & 50 & 5.8 & 13 & 4.9 & \\
\hline $65+$ & 63 & 7.3 & 11 & 4.2 & \\
\hline
\end{tabular}


Table 1. Cont.

\begin{tabular}{|c|c|c|c|c|c|}
\hline & \multicolumn{2}{|c|}{ Migrant-Headed (Rural Born) } & \multicolumn{2}{|c|}{ Non-Migrant-Headed (Nairobi-Born) } & \multirow{2}{*}{$p$-Value } \\
\hline \multicolumn{5}{|l|}{$\begin{array}{c}\text { Education Level of } \\
\text { Household Head }\end{array}$} & \\
\hline None & 6 & 0.7 & 3 & 1.1 & \multirow[t]{4}{*}{$<0.001$} \\
\hline Primary school & 151 & 17.8 & 20 & 7.7 & \\
\hline Secondary school & 348 & 41.0 & 82 & 31.4 & \\
\hline Higher & 343 & 40.4 & 156 & 59.8 & \\
\hline \multicolumn{5}{|l|}{$\begin{array}{c}\text { Employment Status of } \\
\text { Household Head }\end{array}$} & \multirow{6}{*}{0.062} \\
\hline Self-employed & 329 & 38.2 & 111 & 42.0 & \\
\hline Employed full-time & 353 & 41.0 & 113 & 42.8 & \\
\hline $\begin{array}{l}\text { Employed part-time (inc } \\
\text { casual) }\end{array}$ & 128 & 14.8 & 27 & 10.2 & \\
\hline Unemployed & 34 & 3.9 & 6 & 2.3 & \\
\hline Other & 18 & 2.1 & 7 & 2.7 & \\
\hline \multicolumn{5}{|l|}{ Health Status } & \multirow{3}{*}{0.459} \\
\hline Healthy & 810 & 94.3 & 246 & 92.8 & \\
\hline Unhealthy & 49 & 5.7 & 19 & 7.2 & \\
\hline \multicolumn{5}{|l|}{ Household Characteristics } & \multirow{4}{*}{0.003} \\
\hline Food security & & & & & \\
\hline Food secure & 220 & 25.3 & 91 & 34.6 & \\
\hline Food insecure & 651 & 74.7 & 172 & 65.4 & \\
\hline \multicolumn{5}{|l|}{ Household size } & \multirow{5}{*}{0.719} \\
\hline 1 person & 151 & 17.3 & 48 & 18.1 & \\
\hline 2-3 persons & 313 & 35.9 & 94 & 35.5 & \\
\hline $4-5$ persons & 299 & 34.3 & 84 & 31.7 & \\
\hline $6+$ persons & 108 & 12.4 & 39 & 14.7 & \\
\hline \multicolumn{5}{|l|}{ Household Type } & \multirow{6}{*}{0.755} \\
\hline Female-centred & 140 & 16.1 & 48 & 18.0 & \\
\hline Male-centred & 172 & 19.8 & 58 & 21.8 & \\
\hline Nuclear & 491 & 56.5 & 139 & 52.3 & \\
\hline Extended & 63 & 7.2 & 18 & 6.8 & \\
\hline Other & 3 & 0.3 & 3 & 1.1 & \\
\hline \multicolumn{5}{|l|}{ Type of Dwelling } & \multirow{3}{*}{0.057} \\
\hline Formal & 753 & 93.4 & 241 & 93.4 & \\
\hline Informal & 84 & 6.6 & 17 & 6.6 & \\
\hline \multicolumn{5}{|l|}{ Main Source of HH Income } & \multirow{5}{*}{0.020} \\
\hline Formal wage work & 401 & 46.4 & 137 & 52.3 & \\
\hline Informal wage work & 265 & 30.6 & 53 & 20.2 & \\
\hline Self-employment (Informal) & 101 & 11.7 & 40 & 15.3 & \\
\hline Self-employment (formal) & 96 & 11.1 & 30 & 11.5 & \\
\hline
\end{tabular}


Table 1. Cont.

\begin{tabular}{|c|c|c|c|c|c|}
\hline & \multicolumn{2}{|c|}{ Migrant-Headed (Rural Born) } & \multicolumn{2}{|c|}{ Non-Migrant-Headed (Nairobi-Born) } & $p$-Value \\
\hline \multicolumn{6}{|c|}{ Total Monthly HH Income } \\
\hline $\mathrm{KES}<=10,000$ & 136 & 26.0 & 29 & 18.4 & \multirow{6}{*}{$<0.001$} \\
\hline KES 10,001-20,000 & 137 & 26.2 & 22 & 13.9 & \\
\hline KES 20,001-30,000 & 66 & 12.6 & 24 & 15.2 & \\
\hline KES 30,001-40,000 & 36 & 6.9 & 6 & 3.8 & \\
\hline KES 40,001-50,000 & 27 & 5.2 & 3 & 1.8 & \\
\hline$>$ KES 50,000 & 121 & 23.1 & 74 & 46.8 & \\
\hline \multicolumn{6}{|l|}{ LPI Score } \\
\hline $0-0.5$ & 560 & 65.8 & 204 & 77.6 & \multirow{4}{*}{0.001} \\
\hline $0.51-1.00$ & 176 & 20.7 & 39 & 14.8 & \\
\hline $1.01-1.50$ & 73 & 8.6 & 17 & 6.5 & \\
\hline$>1.5$ & 42 & 4.9 & 3 & 1.1 & \\
\hline \multicolumn{6}{|c|}{$\%$ of HH Income on Food } \\
\hline$<20 \%$ & 220 & 43.4 & 75 & 49.3 & \multirow{4}{*}{0.648} \\
\hline $21-35 \%$ & 105 & 20.7 & 30 & 19.7 & \\
\hline $36-50 \%$ & 90 & 17.8 & 26 & 17.1 & \\
\hline$>50 \%$ & 91 & 17.9 & 21 & 13.8 & \\
\hline \multicolumn{5}{|l|}{ Experienced Shocks } & \multirow{3}{*}{0.002} \\
\hline No & 300 & 34.7 & 117 & 45.2 & \\
\hline Yes & 564 & 64.3 & 142 & 54.8 & \\
\hline \multicolumn{5}{|l|}{ Economic shocks } & \multirow{3}{*}{0.003} \\
\hline No & 354 & 40.9 & 138 & 51.4 & \\
\hline Yes & 512 & 59.1 & 126 & 48.6 & \\
\hline \multicolumn{5}{|l|}{ Sociopolitical shocks } & \multirow{3}{*}{0.141} \\
\hline No & 712 & 82.2 & 221 & 85.3 & \\
\hline Yes & 154 & 17.8 & 38 & 14.7 & \\
\hline \multicolumn{5}{|l|}{ Biophysical shocks } & \multirow{3}{*}{0.472} \\
\hline No & 782 & 90.3 & 235 & 90.4 & \\
\hline Yes & 84 & 9.7 & 24 & 9.6 & \\
\hline \multicolumn{5}{|l|}{ Sent Remittances } & \multirow{3}{*}{0.075} \\
\hline Yes & 395 & 46.3 & 107 & 41.0 & \\
\hline No & 458 & 53.4 & 154 & 59.0 & \\
\hline \multicolumn{5}{|c|}{$\begin{array}{c}\text { Received Food Transfers } \\
\text { from Rural Areas }\end{array}$} & \multirow[b]{3}{*}{0.328} \\
\hline Yes & 452 & 52.4 & 122 & 54.1 & \\
\hline No & 411 & 47.6 & 144 & 45.9 & \\
\hline
\end{tabular}


Table 1. Cont.

\begin{tabular}{ccccc}
\hline & Migrant-Headed (Rural Born) & Non-Migrant-Headed (Nairobi-Born) & $p$-Value \\
\hline $\begin{array}{c}\text { Frequency of Food } \\
\text { Transfers from Rural Areas }\end{array}$ & 4 & 1.0 & 5 & 1.1 \\
\hline Weekly & 275 & 66.9 & 297 & 66.7 \\
\hline Monthly & 131 & 31.9 & 142 & 31.9 \\
\hline Yearly & 1 & 0.2 & 1 & 0.435 \\
\hline Less than once per year & & & 0.2 \\
\hline
\end{tabular}

There are also similarities between households headed by migrants and those headed by non-migrants, especially in household size and household typology. Both have similar proportions of one person households (17\% and $18 \%)$, two-five person households (70\% and $68 \%$ ) and larger households (12\% and $15 \%)$. In terms of household type, $16 \%$ of migrant households were female-centred, compared with $18 \%$ of nonmigrant-headed households. The difference in all other categories was $4 \%$ or less. The primary differences between migrant and non-migrant households are economic in nature. As regards the primary source of household income, for example, significantly more migrant households have informal wage work as their main source of income (31\% and $20 \%$ ). The income source and employment profile translate into marked variations in household income, lived poverty, and food insecurity. For example, $52 \%$ of migrant households are in the lowest two income quintiles, compared with $33 \%$ of non-migrant households. For another example, $78 \%$ of non-migrant households have a (better) LPI of between 0.0 and 0.5 , compared with $66 \%$ of migrant households. When it comes to levels of food security, only $25 \%$ of migrant households are classified as completely food secure on the HFIAP scale, compared to $35 \%$ of non-migrant households. Migrant households also tend to spend a greater proportion of their income on food (a surrogate measure of food insecurity). In terms of vulnerability to sudden shocks, more migrant households had experienced economic shocks in the previous year (at 59\%), although non-migrant households were far from immune (at $48 \%$ ). Vulnerability to biophysical and sociopolitical shocks was very similar for both groups.

The most significant finding from the descriptive comparison of migrant and nonmigrant households relates to variables more commonly associated with migration and migrant behaviour. For example, $46 \%$ of migrant households sent cash remittances to the rural areas in the previous year, but so did $41 \%$ of non-migrant households. Contrary to expectations, non-migrant households were marginally more likely to have received food remittances from rural areas in the previous year ( $54 \%$ versus $52 \%$ ). The frequency of receiving food remittances was very similar for both groups. These findings suggest that the whole idea that it is only migrants who engage in sending cash remittances and receiving food remittances needs to be completely rethought in the Nairobi context. Despite being born in Nairobi, the data seem to confirm that non-migrant households continue to maintain strong connections with rural homes. In other words, migration status does not appear to be a good predictor of rural-urban food transfers in the Nairobi case.

To confirm this observation and to assess whether there are better predictors of the propensity of Nairobi households to be involved in food remitting, the results of three multiple logistic regression models are presented for all migrant and non-migrant households that had received food remittances in the previous year. Half of all surveyed households in Nairobi rely to varying degrees on an informal, non-marketed supply of food from their relatives and friends in urban and rural areas. While the food transfers come from both urban and rural areas, the importance of rural food sources is particularly evident, especially from relatives. Eight out of every ten households receiving food transfers obtain them from relatives in the rural areas (Table 2). Figure 1 shows that food transfers from 
the rural areas include cereals (primarily maize); roots and tubers (primarily potatoes); vegetables (primarily traditional vegetables); fruits; meat products (primarily chicken); and beans, peas, lentils, and nuts.

Table 2. Geographical Origin of Household Food Remittances.

\begin{tabular}{cccc}
\hline & $\begin{array}{c}\text { No. of Households } \\
\text { Receiving Transfers }\end{array}$ & \% of Total Sample & $\begin{array}{c}\text { \% of Households Receiving } \\
\text { Food Transfers }\end{array}$ \\
\hline Relatives in rural areas & 645 & 45.6 & 80.6 \\
Friends in rural areas & 40 & 2.8 & 5.0 \\
Relatives in other urban areas & 64 & 4.5 & 8.0 \\
Friends in other urban areas & 51 & 3.6 & 6.4 \\
\hline
\end{tabular}

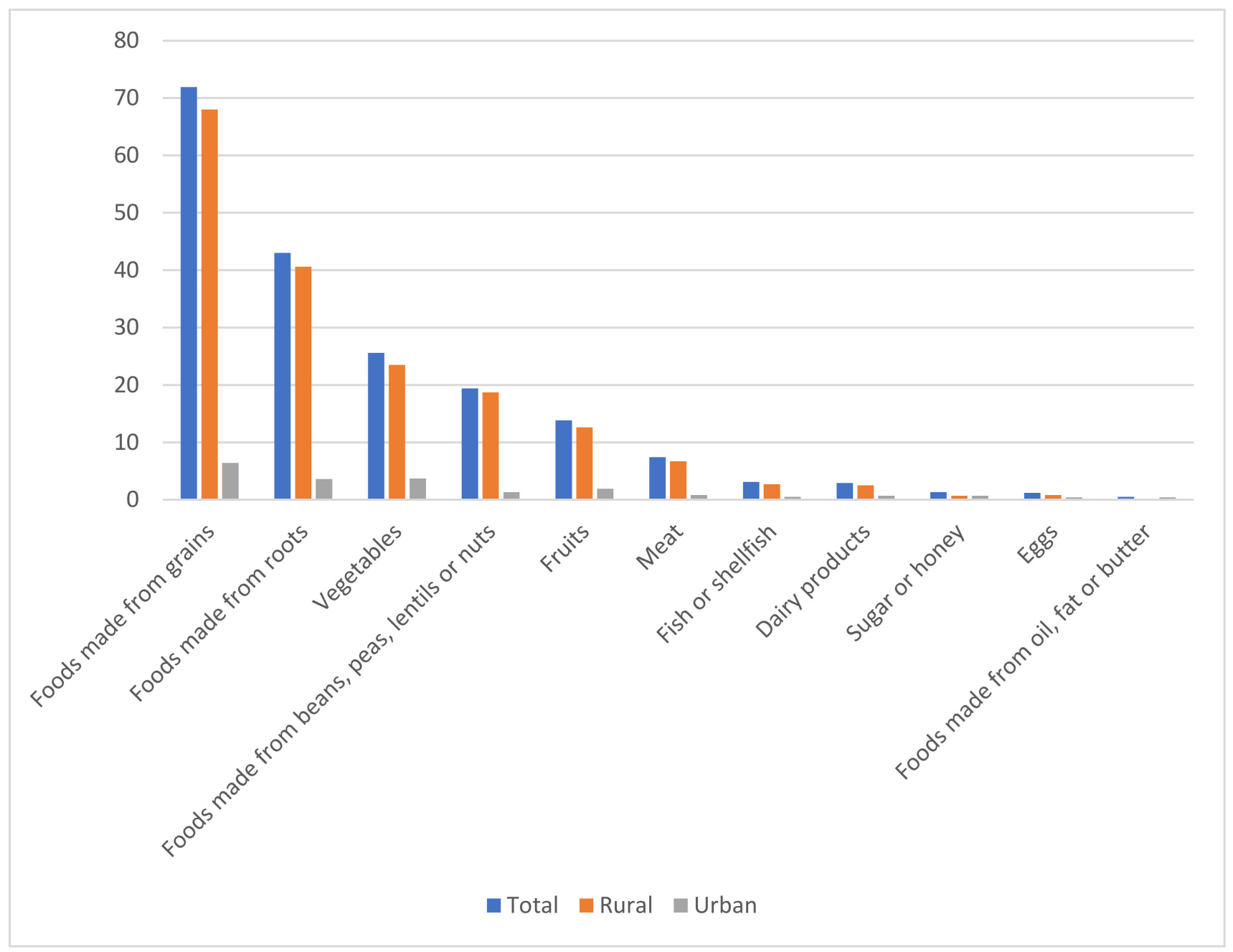

Figure 1. Food Remittances by Type and Geographical Origin.

The frequency of food transfers from rural areas varies between once per week and once per year (Figure 2). However, most recipient households in Nairobi receive regular food transfers "at least 3-6 times in a year". Frequency depends on such factors as cropping seasons, how often an urban dweller travels to the rural areas and vice versa, and the availability and convenience of food transfers through other means. The frequency profile for the different food types is relatively consistent, although vegetables tend to be sent more frequently. The importance of food transfers to the household was measured subjectively by how much the transferred food matters to the households 
involved. Most of the households receiving food transfers indicated that the food source is either very important $(46 \%)$ or important $(40 \%)$ to their survival. The need for additional food is the most important motive for food transfers. Over three-quarters $(80 \%)$ of the households receiving food transfers said that they engaged in the practice to help the household feed itself. For about one-quarter of the households, the food was sent as gifts.

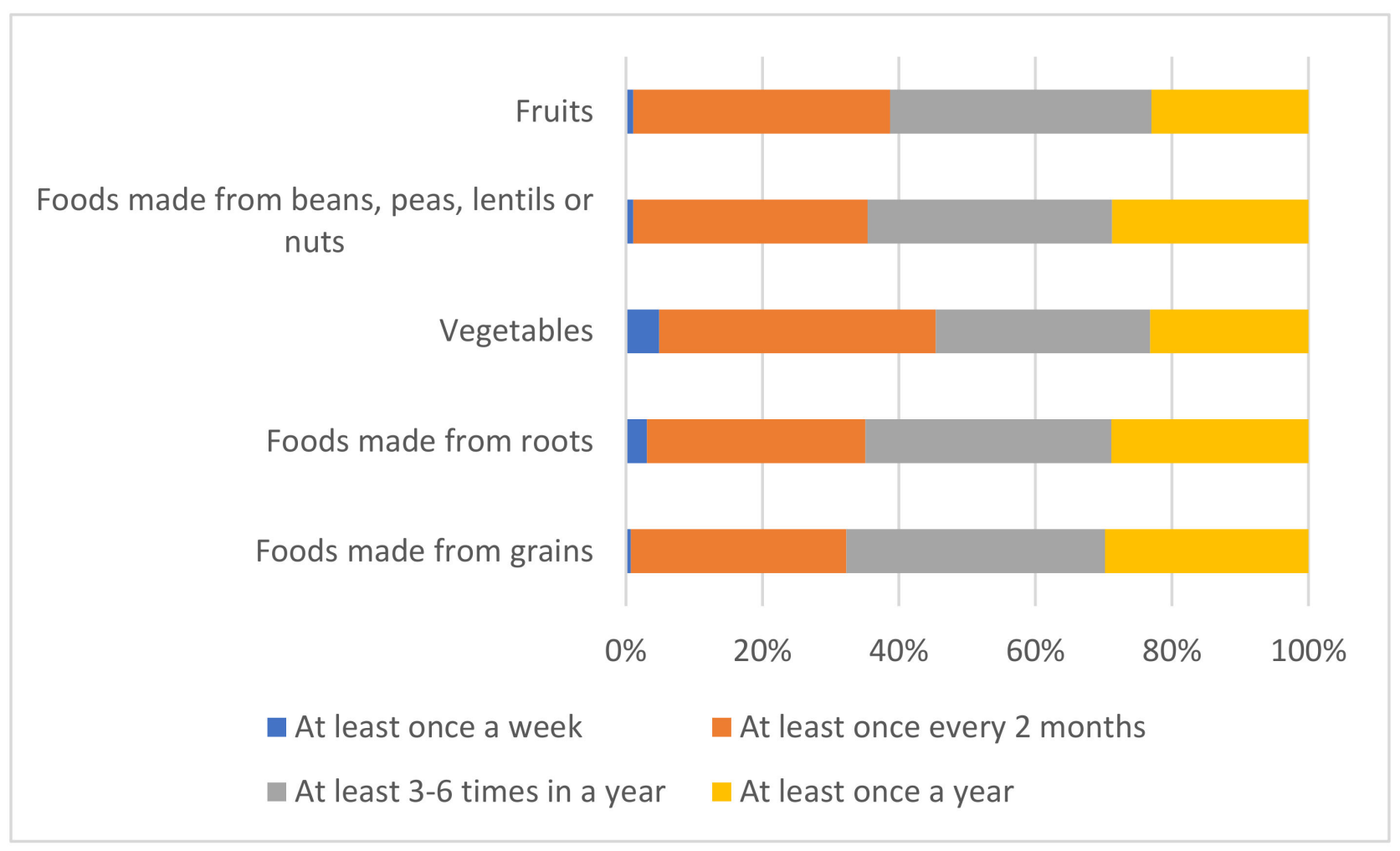

Figure 2. Frequency of Food Transfers from Rural Areas.

Model 1 of the multiple logistical regression includes only individual characteristics of household heads in the logistic regression to test whether the odds of receiving remittances vary with the characteristics of household heads (Table 3). Model 2 includes household characteristics to assess whether certain types of household are more likely to receive remittances. Finally, Model 3 adds household shocks to the analysis to determine if these sudden shocks to the household are likely to lead to food remittances in response. Model 1 confirms that there is no significant statistical difference between households headed by migrants and those headed by non-migrants in the likelihood of receiving food remittances (OR $=1.170$ 95\% CI 0.875-1.565). Female-headed households are marginally more likely than male-headed households to receive transfers but, again, the difference is insignificant (OR $=1.181$ 95\% CI 0.853-1.634). The likelihood of receiving transfers does not consistently decline with the age of the household head, which confirms that length of residence in Nairobi does not have a significant impact on the likelihood of receiving food transfers. Model 1 does show that better-educated heads are more likely to receive food remittances, as are those in full-time wage employment when compared with the self-employed and those with part-time employment (OR 1.449 95\% CI 1.109-1.894). Unemployed household heads are least likely to receive transfers (OR: 0.815 95\% CI 0.453-1.597). 
Model 2 includes household characteristics and suggests that larger households and female-centred households are marginally more likely to be receiving food transfers than smaller households and other types of households. However, female-centred households and nuclear households (most of which are male-headed) have very similar odds ratios, which suggests that type of household is not a significant predictor of food remittances. Households whose main source of income is formal wage employment have increased odds of receiving food remittances compared with all other types. Confirming the household head findings from Model 1, households whose main source of income is self-employment are least likely to receive food remittances (OR: 0.406 95\% CI 0.156-1.056). In addition, households with higher total income are more likely to receive food remittances than those with lower incomes. A comparison of households in the highest and lowest income quintiles, for example, suggests that the latter are significantly less likely to receive food remittances (OR: 0.471 95\% CI 0.234-0.948). Finally, there was no significant difference in the likelihood of receiving food remittances between households that did and did not send cash remittances to rural relatives.

Model 3 assesses whether there is any association between vulnerability to household shocks and the likelihood of receiving food remittances. However, for each of the three categories of shock-economic, sociopolitical, and biophysical-Model 3 shows no significant difference in the likelihood of receiving food between those households experiencing and not experiencing a shock.

Table 3. Multivariate Analysis of Food Remittances to Urban Households.

\begin{tabular}{|c|c|c|c|}
\hline & Adjusted Models & Adjusted Models & Adjusted Models \\
\hline & OR $(95 \% \mathrm{CI})$ & OR $(95 \% \mathrm{CI})$ & OR $(95 \% \mathrm{CI})$ \\
\hline & Model 1 & Model 2 & Model 3 \\
\hline \multicolumn{4}{|c|}{ Household Head Demographics } \\
\hline \multicolumn{4}{|c|}{ Migrant status of household head (ref $=$ migrant) } \\
\hline Non-migrant & $1.170(0.875-1.565)$ & $1.008(0.668-1.520)$ & $0.991(0.652-1.505)$ \\
\hline \multicolumn{4}{|c|}{ Sex of household head (ref = Male) } \\
\hline Female & $1.181(0.853-1.634)$ & $1.064(0.386-2.932)$ & $1.102(0.399-3.043)$ \\
\hline \multicolumn{4}{|c|}{ Age of household head $(\mathrm{ref}=16-24)$} \\
\hline $25-34$ & $1.148(0.717-1.837)$ & $1.037(0.548-1.963)$ & $1.064(0.558-2.031)$ \\
\hline $35-44$ & $1.561(0.970-2.513) *$ & $1.604(0.813-3.164)$ & $1.648(0.829-3.276)$ \\
\hline $45-54$ & $1.275(0.749-2.171)$ & $1.198(0.559-2.566)$ & $1.30(0.601-2.810)$ \\
\hline $55-64$ & $0.939(0.467-1.888)$ & $1.544(0.569-4.188)$ & $1.531(0.552-4.250)$ \\
\hline $65+$ & $1.338(0.691-2.589)$ & $2.622(0.762-9.018)$ & $2.893(0.807-10.371)$ \\
\hline \multicolumn{4}{|c|}{ Education level of household head (ref = no education) } \\
\hline Primary school & $0.666(0.185-2.392)$ & $2.116(0.197-22.753)$ & $2.389(0.211-27.056)$ \\
\hline Secondary school & $0.946(0.268-3.333)$ & $3.731(0.355-39.261)$ & $3.962(0.359-43.727)$ \\
\hline Higher & $1.441(0.409-5.077)$ & $4.585(0.433-48.596)$ & $4.915(0.443-54.564)$ \\
\hline \multicolumn{4}{|c|}{ Employment status of household head (ref = self-employed) } \\
\hline Employed full-time & $1.449(1.109-1.894) * * *$ & $1.214(0.767-1.921)$ & $1.157(0.727-1.841)$ \\
\hline Employed part-time & $1.470(1.011-2.138) * *$ & $1.188(0.680-2.075)$ & $1.159(0.661-2.035)$ \\
\hline Unemployed & $0.815(0.453-1.597)$ & $0.406(0.156-1.056) *$ & $0.417(0.160-1.088) *$ \\
\hline
\end{tabular}


Table 3. Cont.

\begin{tabular}{|c|c|c|c|}
\hline & Adjusted Models & Adjusted Models & Adjusted Models \\
\hline & OR $(95 \% \mathrm{CI})$ & OR $(95 \% \mathrm{CI})$ & OR $(95 \% \mathrm{CI})$ \\
\hline & Model 1 & Model 2 & Model 3 \\
\hline \multicolumn{4}{|c|}{ Household Characteristics } \\
\hline \multicolumn{4}{|c|}{ Household size (ref = 1 person) } \\
\hline $2-3$ persons & & $0.950(0.582-1.553)$ & $0.964(0.587-1.584)$ \\
\hline $4-5$ persons & & $1.239(0.752-2.043)$ & $1.230(0.740-2.045)$ \\
\hline $6+$ persons & & $1.477(0.849-2.569)$ & $1.457(0.834-2.545)$ \\
\hline \multicolumn{4}{|c|}{ Household type (ref = female-centred) } \\
\hline Male-centred & & $0.752(0.260-2,177)$ & $0.753(0.259-2.189)$ \\
\hline Nuclear & & $1.062(0.380-2.968)$ & $1.081(0.385-3.033)$ \\
\hline Extended & & $0.705(0.214-2.319)$ & $0.640(0.193-2.119)$ \\
\hline \multicolumn{4}{|c|}{ Main source of household income (ref = formal wage work) } \\
\hline Informal wage work & & $0.967(0.594-1.575)$ & $1.002(0.613-1.637)$ \\
\hline Self-employment (informal) & & $0.586(0.318-1.083) *$ & $0.591(0.320-1.095)$ \\
\hline Self-employment (formal) & & $0.907(0.477-1.722)$ & $0.871(0.456-1.665)$ \\
\hline \multicolumn{4}{|c|}{ Total household income $(>$ KES50,000) } \\
\hline $\mathrm{KES} \leq 10,000$ & & $0.471(0.234-0.948) * *$ & $0.477(0.236-0.965) * *$ \\
\hline KES 10,001-20,000 & & $0.726(0.405-1.300)$ & $0.731(0.406-1.316)$ \\
\hline KES 20,001-30,000 & & $0.693(0.381-1.260)$ & $0.687(0.376-1.256)$ \\
\hline KES 30,001-40,000 & & $1.005(0.474-2.133)$ & $0.991(0.463-2.123)$ \\
\hline KES 40,001-50,000 & & $0.802(0.352-1.828)$ & $0.782(0.335-1.824)$ \\
\hline \multicolumn{4}{|c|}{ Sends remittances $(\mathrm{ref}=\mathrm{no})$} \\
\hline Yes & & $1.161(0.832-1.620)$ & $1.140(0.814-1.597)$ \\
\hline \multicolumn{4}{|c|}{ Household Shocks/Emergencies } \\
\hline \multicolumn{4}{|c|}{ Experienced shock $($ ref $=$ no $)$} \\
\hline Yes & & & $0.942(0.405-2.193)$ \\
\hline \multicolumn{4}{|l|}{ Economic shocks $(r e f=n o)$} \\
\hline Yes & & & $1.192(0.550-2.557)$ \\
\hline \multicolumn{4}{|l|}{ Social shocks $(r e f=n o)$} \\
\hline Yes & & & $1.014(0.633-1.624$ \\
\hline \multicolumn{4}{|l|}{ Biophysical shock $(r e f=n o)$} \\
\hline Yes & & & $0.668(0.383-1.163)$ \\
\hline
\end{tabular}

Legend: HH—Household; LPI—Lived Poverty Index; Net monthly income in Kenyan Shillings; Significance level: ${ }^{* * *} p \leq 0.01 . ;{ }^{* *} p \leq 0.05$; $* p \leq 0.1$.

\section{Conclusions}

The current literature suggests that informal food remitting from countryside to city in urbanizing Africa has several common characteristics. First, this phenomenon is an essentially transitional phase in the longer-term urbanization of the continent. As more and more people, especially the young, move out of the drudgery and limited opportunities of rural life and settle in urban areas, their links with those left behind-especially the elderly-will eventually weaken and dissolve. Second, the phenomenon of food remitting 
is tied to and a direct consequence of rural-to-urban migration and needs to be understood as a strategy by divided or multi-nodal households to bolster migrant survival in the city. As one study argues, "migrants survive in the urban areas in part because of the food they receive from the rural areas" [41] (p. 104). Third, food remitting calls into question the traditional linear conception of rural-urban linkages as a one-way flow of migrants to the city and a one-way return flow of remittances. Instead, food remittances should be seen as part of an integrated system of urban-rural reciprocity, in which food flows to the city to support the migrant and cash flows to the countryside once the migrant has a steady and reliable source of income. Finally, there is an assumption that (predominantly migrant) urban households experiencing high levels of poverty, precarious employment, and food insecurity are more likely to need and to receive food remittances in order to meet their basic needs.

All four arguments are challenged by the survey findings reported for Nairobi in this study. In Kenya, far from being a transitory phenomenon on the road to full urbanization, linkages with the rural areas remain strong and resilient. One indication of this is that migrants of all ages (and therefore all lengths of urban residence) continue to receive food remittances from the countryside. Insofar as this is an indicator of resilient links between rural and urban areas and divided households, the findings provide additional support for the argument of previous Kenyan researchers that urban residents who have migrated to Nairobi maintain very strong rural links throughout their life. Another indicator of the strength of links is the practice of urban household members returning periodically to rural homes to take part in agricultural cultivation $[18,55,56]$, a practice engaged in by $29 \%$ of households in the survey. Second, food remittances in Kenya are not purely a migration-related phenomenon, as conventional wisdom might suggest. As many as $54 \%$ of households with Nairobi-born heads of households had received food remittances in the previous year (compared with $52 \%$ of households with migrant heads). Third, the survey found no strong evidence for the phenomenon of urban-rural remittances reciprocity, in that there was no significant relationship between a household's propensity to remit cash and its receipt of food remittances from rural areas. Finally, while food remitting has hitherto been associated with urban poverty, precarity, and the struggle for survival, the Nairobi evidence suggests that better-off, higher-income households with household members in wage employment are more likely to be receiving food remittances. This finding is consistent with emerging evidence from rural areas in Kenya and elsewhere that better-off rural households tend to remit more food than poorer households [57]. Since higher-income households in Nairobi generally have lower levels of food insecurity and spend a smaller portion of household income on food, food remittances in this context may be seen more as a way of supplementing and diversifying the household diet with fresh produce and also be more of an indicator of ongoing social ties with relatives in the countryside. However, the stratifying effects of this form of rural-urban linkage for both urban and rural households is worth underlining. To date, the literature on food remitting has tended to focus either on rural senders or urban recipients but not on both simultaneously. Studies of this nature are necessary to fully understand the motivations behind and impacts of food remitting and its role in perpetuating rural-urban linkages and deepening rural and urban inequality.

Author Contributions: Conceptualization, J.C.; methodology, S.O., J.C.; validation, E.O.O.; formal analysis, E.O.O.; investigation, E.O.O., J.C., S.O.; resources, S.O.; data curation, S.O.; writingoriginal draft preparation, E.O.O.; writing—review and editing, J.C.; supervision, S.O., J.C.; project administration, J.C., S.O.; funding acquisition, J.C. All authors have read and agreed to the published version of the manuscript. 
Funding: This research was funded by the International Development Research Centre, grant number 107775-001; the Social Sciences and Humanities Research Council of Canada, grant number 895-20133005; and the Queen Elizabeth Scholars-Advanced Scholars Program.

Institutional Review Board Statement: This Hungry Cities Partnership study was approved by the Ethics in Research Committee of the Faculty of Engineering and the Built Environment at University of Cape Town, South Africa; and the Ethics Review Board of the Office of Research Services, Wilfrid Laurier University, Canada.

Informed Consent Statement: Informed consent was obtained from all participants in the study.

Data Availability Statement: Data from the Hungry Cities Partnership Survey, Nairobi is accessible at DataFirst, University of Cape Town, South Africa (https:/ /www.datafirst.uct.ac.za/dataportal/ index.php/catalog/843, accessed on 27 June 2021).

Conflicts of Interest: The authors declare no conflict of interest.

\section{References}

1. UN (United Nations). World Urbanization Prospects: The 2014 Revision; United Nations: New York, NY, USA, 2015.

2. Fox, S. Urbanisation as a Global Historical Process: Theory and Evidence from Sub-Saharan Africa. In Africa's Urban Revolution; Parnell, S., Pieterse, E., Eds.; Zed Press: London, UK, 2014; pp. 257-283.

3. Fox, S. Mortality, Migration and Rural Transformation in Sub-Saharan Africa's Rural Transformation. J. Demogr. Econ. 2016, 83, 13-30. [CrossRef]

4. Parnell, S.; Pieterse, E. (Eds.) Africa's Urban Revolution; Zed Press: London, UK, 2014; pp. 257-283.

5. Baker, J. (Ed.) Small Town Africa: Studies in Rural-Urban Interaction; Scandinavian Institute of African Studies: Uppsala, Sweden, 1990.

6. Baker, J.; Pedersen, P. (Eds.) The Rural-Urban Interface in Africa: Expansion and Adaptation; Scandinavian Institute of African Studies: Uppsala, Sweden, 1992.

7. Evans, H.E.; Ngau, P. Rural-Urban Relations, Household Income Diversification and Agricultural Productivity. Dev. Chang. 1991, 22, 519-545. [CrossRef]

8. Parkin, D. (Ed.) Town and Country in Central and Eastern Africa; Routledge: London, UK, 1975.

9. Potter, R.; Unwin, T. (Eds.) The Geography of Urban-Rural Interaction in Developing Countries; Routledge: London, UK, 1989.

10. Tacoli, C. (Ed.) Rural-Urban Linkages; Earthscan: London, UK, 2006.

11. Agergaard, J.; Tacoli, C.; Steel, G.; Ørtenblad, S. Revisiting Rural-Urban Transformations and Small Town Development in Sub-Saharan Africa. Eur. J. Dev. Res. 2019, 31, 2-11. [CrossRef]

12. Proctor, F.; Berdegué, J. Food Systems at the Rural-Urban Interface. In Handbook on Urban Food Security in the Global South; Crush, J., Frayne, B., Haysom, G., Eds.; Edward Elgar: Cheltenham, UK, 2020; pp. 166-197.

13. Djurfeldt, A.A. Multi-Local Livelihoods and Food Security in Rural Africa. J. Int. Dev. 2015, 27, 528-545. [CrossRef]

14. Steinbrink, M.; Niedenführ, H. Africa on the Move: Migration, Translocal Livelihoods and Rural Development in Sub-Saharan Africa; Springer: Dordrecht, The Netherlands, 2020.

15. Harris, J.; Todaro, M. Migration, Unemployment, and Development: A Two-Sector Analysis. Am. Econ. Rev. 1970, 60, 126-142.

16. Todaro, M. A Model of Labor Migration and Urban Unemployment in Less Developed Countries. Am. Econ. Rev. 1969, 59, 138-148.

17. Elkan, W. Circular Migration and the Growth of Towns in East Africa. Int. Labour Rev. 1967, 96, 581-589.

18. Oucho, J.; Oucho, L.; Ochieng, V. Is Migration the Solution to Poverty Alleviation in Kenya? Rural-Urban Migration Experiences of Migrants from Western Kenya to Kisumu and Nairobi; Migrating Out of Poverty Working Paper No. 21; Sussex University: Brighton, UK, 2014.

19. Mberu, B.; Ezeh, A.; Chepngeno-Langat, G.; Ezeh, A.; Kimani, J.; Beguy, D. Family Ties and Urban-Rural Linkages among Older Migrants in Nairobi Informal Settlements. Popul. Space Place 2013, 19, 275-293. [CrossRef]

20. Bang, J.; Mitra, A.; Wunnava, P. Do Remittances Improve Income Inequality? An Instrumental Variable Quantile Analysis of the Kenyan Case. Econ. Model. 2016, 58, 394-402. [CrossRef]

21. Jena, F. Migrant Remittances and Physical Investment Purchases: Evidence from Kenyan Households. J. Dev. Stud. 2017, 54, 312-326. [CrossRef]

22. Maara, J.; Manda, D.; Kiiru, J. Remittances and Household Expenditure Allocation Behavior in Kenya. Afr. J. Econ. Rev. 2019, 7, 85-108.

23. Kingiri, A.; Fu, X. Understanding the Diffusion and Adoption of Digital Finance Innovation in Emerging Economies: M-Pesa Money Mobile Transfer Service in Kenya. Innov. Dev. 2020, 10, 67-87. [CrossRef] 
24. Formy, R. The Impact of Mobile Money on Remittance Recipients' Household Welfare and Education: Evidence from Kenya. In Migration, Remittances and Sustainable Development in Africa; Konte, M., Mbaye, L., Eds.; Routledge: New York, NY, USA, 2021; pp. 157-176.

25. Lacroix, T. Migration, Rural Development, Poverty and Food Security: A Comparative Perspective; International Migration Institute, Oxford University: Oxford, UK, 2011.

26. Crush, J. Linking Migration, Development and Urban Food Security. Int. Migr. 2013, 51, 61-75. [CrossRef]

27. Crush, J.; Caesar, M. Cultivating the Migration-Food Security Nexus. Int. Migr. 2017, 55, 19-27. [CrossRef]

28. Chikanda, A.; Crush, J.; Tawodzera, G. Urban Food Security and South-South Migration to Cities of the Global South. In Handbook on Urban Food Security in the Global South; Crush, J., Frayne, B., Haysom, G., Eds.; Edward Elgar: Cheltenham, UK, 2020; pp 261-281.

29. Atuoye, K.; Kiuure, V.; Kangmennaang, J.; Antabe, R.; Luginaah, I. Residential Remittances and Food Security in the Upper West Region of Ghana. Int. Migr. 2017, 55, 18-34. [CrossRef]

30. Mabrouk, F.; Mekni, M.M. Remittances and Food Security in African Countries. Afr. Dev. Rev. 2018, 30, 252-263. [CrossRef]

31. Sulemana, I.; Anarfo, E.B.; Quartey, P. International remittances and household food security in Sub-Saharan Africa. Migr. Dev. 2019, 8, 264-280. [CrossRef]

32. Ebadi, N.; Ahmadi, D.; Melgar-Quiñonez, H. Domestic and International Remittances and Food Security in Sub-Saharan Africa. Remit. Rev. 2020, 5, 37-54. [CrossRef]

33. Tshikala, S.; Konstandini, G.; Fonsah, E. The Impact of Migration, Remittances and Public Transfers on Technology Adoption: The Case of Cereal Producers in Rural Kenya. J. Agric. Econ. 2019, 17, 316-331. [CrossRef]

34. Tacoli, C.; Vorley, B. Reframing the Debate on Urbanisation, Rural Transformation and Food Security; IIED Briefing: London, UK, 2015.

35. Crush, J.; Pendleton, W. Remitting for Survival: Rethinking the Development Potential of Remittances in Southern Africa. Glob. Dev. Stud. 2009, 5, 53-84.

36. Crush, J.S.; Caesar, M.S. Food remittances and food security: A review. Migr. Dev. 2017, 7, 180-200. [CrossRef]

37. Frayne, B. Pathways of food: Mobility and food transfers in Southern African cities. Int. Dev. Plan. Rev. 2010, 32, 291-310. [CrossRef]

38. Frayne, B.; Crush, J. Food Supply and Urban-Rural Links in Southern African Cities. In Food and Nutrition Security in Southern African Cities; Frayne, B., Crush, J., McCordic, C., Eds.; Routledge: London, UK, 2018; pp. 34-47.

39. Djurfeldt, A.A. Virtuous and Vicious Cycles in Rural-Urban Linkages: Cases from Zimbabwe. Afr. Rev. 2012, 4, 136-156. [CrossRef]

40. Frayne, B. Migration and urban survival strategies in Windhoek, Namibia. Geoforum 2004, 35, 489-505. [CrossRef]

41. Frayne, B. Migration and the changing social economy of Windhoek, Namibia. Dev. S. Afr. 2007, 24, 91-108. [CrossRef]

42. Nickanor, N.; Crush, J.; Pendleton, W. Migration, Rural-Urban Linkages and Food Insecurity. In Rapid Urbanisation, Urban Food Deserts and Food Security in Africa; Crush, J., Battersby, J., Eds.; Springer: Dordrecht, The Netherlands, 2016 ; pp. 127-142.

43. Owuor, S. Migrants, Urban Poverty and the Changing Nature of Urban-Rural Linkages in Kenya. In Surviving on the Move: Migration, Poverty and Development in Southern Africa; Crush, J., Frayne, B., Eds.; Idasa Publishing: Cape Town, South Africa, 2010; pp. 117-131.

44. Tawodzera, G.; Godfrey, T. Rural-Urban Transfers and Household Food Security in Harare's Crisis Context. J. Food Nutr. Disord. 2013, 2, 5. [CrossRef]

45. Owuor, S. The State of Household Food Security in Nairobi, Kenya; Report No. 11; Hungry Cities Partnership: Cape Town, South Africa, 2018.

46. Mattes, R. Lived Poverty on the Rise: Decades of Living Standards Gains Ends in Africa; Policy Paper No. 62; Afrobarometer: Cape Town, South Africa, 2020.

47. KNBS. 2019 Kenya Population and Housing Census; Kenya National Bureau of Statistics: Nairobi, Kenya, $2019 ;$ Volume I.

48. Emina, J.; Beguy, D.; Zulu, E.M.; Ezeh, A.C.; Muindi, K.; Elung'ata, P.; Otsola, J.K.; Yé, Y. Monitoring of Health and Demographic Outcomes in Poor Urban Settlements: Evidence from the Nairobi Urban Health and Demographic Surveillance System. J. Urban Health 2011, 88, 200-218. [CrossRef]

49. Otiso, K. Profile of Nairobi, Kenya; Berkshire Publishing Group: Nairobi, Kenya, 2014.

50. Awuor, V.; Odipo, G.; Agwanda, A. Age schedules of intra-provincial migration in Kenya. Afr. Popul. Stud. 2018, 32, 4356-4375. [CrossRef]

51. Oucho, L. The Impact of Internal Migration of Youth in Developing Sustainable Counties in Kenya. In Migration, Remittances and Sustainable Development in Africa; Konte, M., Mbaye, L., Eds.; Routledge: New York, NY, USA, 2021; pp. $62-81$.

52. LaRue, K.; Daum, T.; Mausch, K.; Harris, D. Who Wants to Farm? Answers Depend on How You Ask: A Case Study on Youth Aspirations in Kenya. Eur. J. Dev. Res. 2021, 33, 885-909. [CrossRef]

53. Nakamura, S.; Avner, P. Spatial Distributions of Job Accessibility, Housing Rents, and Poverty in Nairobi, Kenya; Research Working Paper No. 8654; World Bank: Washington, DC, USA, 2018.

54. Mugisha, F. School Enrollment Among Urban Non-Slum, Slum and Rural Children in Kenya: Is the Urban Advantage Eroding? Int. J. Educ. Dev. 2006, 26, 471-482. [CrossRef] 
55. Djurfeldt, A.A. Seasonality and farm/non-farm interactions in Western Kenya. J. Mod. Afr. Stud. 2012, 50, 1-23. [CrossRef]

56. Ramisch, J.J. "Never at ease": Cellphones, multilocational households, and the metabolic rift in western Kenya. Agric. Hum. Values 2015, 33, 979-995. [CrossRef]

57. Djurfeldt, A.A.; Wambugu, S.K. In-kind transfers of maize, commercialization and household consumption in Kenya. J. East. Afr. Stud. 2011, 5, 447-464. [CrossRef] 